\title{
The Effect of Religiosity and Social Influence on the Intention to Use Sharia Banks in Aceh Singkil Regency
}

\author{
Purwanto $^{1 *}$, Yeny Fitriyani ${ }^{1}$, Titis Rosowulan ${ }^{2}$, Saebani $^{3}$, Milna Wafirah $^{3}$, M Pudail $^{1}$
}

\author{
${ }^{I}$ Sharia Economic Studies, Al Husain Islamic College, Magelang, Indonesia \\ ${ }^{2}$ Qur'an and exegesis Studies, Al Husain Islamic College, Magelang, Indonesia \\ ${ }^{3}$ Islamic Education Management Studies, Al Husain Islamic College, Magelang, Indonesia \\ *Corresponding author. Email: poerwanto073@gmail.com
}

\begin{abstract}
Sharia banks in Indonesia had experienced significant developments in recent years both in terms of quantity and assets. One of the ways undertaken by the Indonesian government in improving the development of Sharia Banks was by converting conventional banks into Sharia Commercial Banks. It has done by the government of the Province of Nanggroe Aceh Darussalam (NAD). This conversion is expected to foster public interest in using Sharia Bank products. The intention to use sharia products from several studies is affected by religiosity and social influence (social support). Therefore, this research is important in order to determine the extent of the effect of religiosity and social influence on people's intentions to use sharia bank products. The method is quantitative research. The number of samples was 100 samples taken randomly in Aceh Singkil District. Data was collected by conducting surveys online and manually. The data analysis is SEM-PLS. The results studies show that religiosity and social influence have a significant effect on the intention to use Sharia banks. In addition, religiosity and social influence has 30.3 percent predictive value (Q2).
\end{abstract}

Keywords: Sharia banks, intention, religiosity, social influence

\section{INTRODUCTION}

Data published by The Pew Forum on Religion \& Public Life, shows that the number of Muslims in Indonesia reached 87.2 or 13.1 percent of the number of Muslims worldwide [1]. The large number of Muslims can become a potential market for the development of sharia-based industries including the financial industry of the sharia banking sector. One of the strategies to maximize this potential is to convert commercial banks into Sharia commercial banks.

This strategy was carried out by the government of Nanggroe Aceh Darussalam (NAD) in 2016. Based on the Decision of the OJK Board of Commissioners Number. KEP-44 / D.03 / 2016 concerning the granting of a License for Changing Business Activities of Conventional Commercial Banks to Sharia Commercial Banks as of September 1, 2016, the Aceh bank has been fully transformed into a sharia commercial bank.

For Sharia banking industry, the conversion of Aceh banks into Aceh Syariah banks had a significant impact on the market share of sharia banks on the sharia banking industry in Indonesia [2]. In addition to having an impact on increasing market share, the conversion carried out by Bank Aceh also impacts naming Aceh Banks. In accordance with the provisions of the Law of the Republic of Indonesia Number 21 Year 2008 concerning Sharia Banking article 15 (4) it is stated that, sharia banks that have obtained business licenses must clearly state the word "sharia" in writing the name of their bank. This means that after making a conversion, the name PT. Bank Aceh must change its brand to PT. Bank Aceh Syariah [2]. Thus, giving the name of PT. Bank Aceh Syariah can create attraction for prospective customers who are Muslim, while for Bank Aceh Syariah this brand change can be one way to show the public that they offer products in accordance with Islamic sharia [2]. Theoretically, a brand is one of the factors that can influence a person to use a product or service. The results of research conducted by Tajudin and Mulazid also prove that brand awareness can determine a person's decision to use Sharia banking products [3]. Other studies also prove that there is a positive influence between brand awareness and consumers' decision to buy halal products [4].

A person's decision to buy a product always starts from the intention. Intention is assumed to be a motivating factor influencing behavior, the stronger the intention to engage in behavior, the more likely it is to behave [5]. Many studies prove that the decision to make a purchase is largely determined by the intention first, [6] [7] [8]. Intention is the desire to adopt, use or accept behavioral actions [8]. In this context the intention to use sharia bank products is the desire of someone to take advantage of financing or saving in sharia banks. Many researchers proved that the intention is a variable which can predict from actual behavior. Therefore, the intention to use sharia banks is a community plan to use Aceh Syariah bank products within a certain period of time and ultimately to use Aceh Sharia bank products significantly [9].

Intention in reality is not only influenced by the brand, but also influenced by religiosity and social influence. Religiosity is as an integrated system of beliefs, lifestyles, ritual activities and institutions that give meaning to human life and direct people to sacred values [10]. Religiosity has 
a large role in influencing individual choices and one's behavior in the social environment. Islam is a religion that regulates human life where the creed determines the rules of a Muslim's beliefs, while Sharia regulates their practices and behavior. Thus, the existence of financial institutions that comply with Sharia standards can affect the intention of a Muslim to use his product [11].

The results of research conducted by Syed Shah Alam, Hawati Janor, Zanariah, Che Aniza Che Wel and Mst. Nilufar Ahsan [12] proves that religiosity has a positive and significant influence on the intention to use sharia bank products. Likewise, research conducted by Mohd Azizi Ibrahim, Wan Nazjmi Mohamed Fisol and Yusuf HajiOthman [13] which proved the results that religiosity has a significant influence on intention to use sharia bank products. Similar research results are also evidenced by research conducted by Hassan Obeid and Souheila Kaabachi [14]. However, research conducted by Nizar Souiden and Marzouki Rani [15] religiosity does not have a direct influence on the intention to use sharia bank products. From the results of research on the effect of religiosity on intentions there has not been a uniform result, where religiosity does not always affect the intention to use sharia bank products.

In addition to the variable religiosity that can affect the intention to use sharia bank products is also influenced by social influence. Social influence is a decision taken by someone based on the actions of those around him [16]. Social influence is a process in which people determine the successful experiences of their social groups in regarding something, before deciding to adopt it. Information from social groups only serves as an additional function, because someone can or does not follow what is suggested. Likewise, positive social influences will influence someone's intention to use the Aceh Sharia Bank. Information from external sources can increase the confidence, confidence to use or utilize Aceh Sharia bank products [17].

The results of research conducted by Nelson Lajuni, Winnie Wong Poh Ming, Yusman Yacob, Hiram Ting and Alfera Jausin prove that social influence has a positive influence on one's intention to use sharia bank products [18]. However, research conducted by Wahyuni Salamah [19] Hassan Obeid and Souheila Kaabachi [14] proved the opposite results, where social influence does not have a significant influence on the intention to use sharia banks. Similar to religiosity, social influence is also not consistent in influencing the intention to use sharia banks.

\section{METHOD}

This research is a field research with a quantitative approach. The population in this study were all residents in Aceh Singkil Regency. As for the sample in this study are residents of Aceh Singkil district who have worked or residents who are included in the category of the workforce totaling 100 people.

Research data is collected online via google form. The statements in the questionnaire were prepared by adopting a questionnaire that had been used by researchers before. The intention and social influence variables use statement items that have been used by Amin, Rahim Abdul Rahman, Laison Sondoh, \& Magdalene Chooi Hwa [20]. As for the variable religiosity using a questionnaire compiled by $\mathrm{M}$. Abou-Youssef, Kortam, Abou-Aish and El-Bassiouny [21]. All research variables will use the Likert Scale in the process of collecting data. Likert Scale in this study will use a score of 1 to 6 as in table 1 below.

Table 1 Table of Categories and Scoring

\begin{tabular}{|lcc|}
\hline \multicolumn{1}{|c}{ Statement } & Symbol & Score \\
\hline Strongly Disagree & STS & 1 \\
\hline Disagree & TS & 2 \\
\hline Somewhat Disagree & ATS & 3 \\
\hline Somewhat Agree & AS & 4 \\
\hline Agree & S & 5 \\
\hline Strongly Agree & SS & 6 \\
\hline
\end{tabular}

Data analysis in this study will use Structural Equation Modeling (SEM) analysis using SmartPLS as an analysis tool. PLS is one method for implementing SEM. This PLS model is used when the basic theory of designing a weak model and measurement indicators do not meet the ideal measurement model. PLS can be used with a number of samples that are not large and can be applied at all data scales [22]. The criteria for evaluating the PLS model as proposed by Chin [22] are as in the following Table 2:

Table 2 PLS Scoring Criterion

\begin{tabular}{|ll|}
\hline Criterion & Explanation \\
\hline & a. Loading factor score more than 0.6 \\
Measuring Model & b. Composite reliability $>0.60$. \\
Evaluation & c. AVE $>0.50$ \\
& d. Cronbachs Alpha $>0.70$ \\
\hline & a. $\mathrm{P}_{\text {value }}<0.05$. \\
Structural Model & b. $f^{2}$ dan $q^{2}$ \\
Evaluation & 1) 0.02 small Effect \\
& 2) 0.15 medium Effect \\
& 3) 0.35 large Effect \\
\hline
\end{tabular}

\section{RESULTS AND DISCUSSION}

\subsection{Profile of Respondents}

This research involved 100 respondents who live in Aceh Singkil Regency. Of the 100 respondents the majority of respondents were women with a percentage of $66 \%$, while female respondents accounted for 34\%. Judging from the age of respondents, the majority of respondents aged 20 to 30 years with a percentage of $60 \%$, then followed by respondents aged less than 20 years by $20 \%$. In terms of education the majority of respondents have a high school education equivalent with a percentage of $88 \%$ and only $6 \%$ of respondents have a college education.

Meanwhile, in terms of the work of the majority of respondents working as entrepreneurs with a percentage of $29 \%$, then respondents who work as private employees with a number of respondents by $20 \%$. Judging from the total monthly income of $59 \%$ receptors who earn less than $\mathrm{Rp}$ 2,500,000 and respondents who earn between Rp 2,500,001 to $\operatorname{Rp} 5,000,000$ with a percentage of $36 \%$. 


\subsection{Estimation and Structural Model}

Estimated data in this study uses SmartPLS 3.0. Reliability testing uses Cronbach $\alpha$. If Cronbach $\alpha$ has a value of 0.7 then the data shows a good level of reliability [23]. Meanwhile, the measurement model is assessed by calculating convergent and discriminant validity values. As for convergent validity purposes, composite reliability (CR) values must be at least 0.7 and the average variance extracted (AVE) must be greater than 0.5 [17]. Meanwhile, the discriminant validity test is fulfilled if the square root of AVE for each construct is greater than the correlation coefficient with other constructs [24]. From the results of the analysis in Table III, both CR and AVE for each construct each variable is greater than 0.7 and 0.5 .

Table 3 Convergent and Discriminant Validity

\begin{tabular}{|lllllll|}
\hline Var & Cronbach' $\boldsymbol{\alpha}$ & Reliability & AVE & NI & RG & SI \\
\hline NI & 0.928 & 0.944 & 0.773 & 0.879 & & \\
\hline RG & 0.930 & 0.942 & 0.648 & 0.548 & 0.805 & \\
\hline SI & 0.925 & 0.943 & 0.768 & 0.637 & 0.551 & 0.876 \\
\hline
\end{tabular}

Note: NI (Intention), RG (Religiosity), SI (social influence);

The diagonal value is the square root of AVE;

Table 4 Measurement Model Cross Loadings

\begin{tabular}{|llll|}
\hline & NI & RG & SI \\
\hline NI1 & 0.873 & 0.378 & 0.449 \\
\hline NI2 & 0.879 & 0.398 & 0.440 \\
\hline NI3 & 0.845 & 0.611 & 0.603 \\
\hline NI4 & 0.919 & 0.428 & 0.534 \\
\hline NI5 & 0.879 & 0.522 & 0.689 \\
\hline RG1 & 0.371 & 0.858 & 0.440 \\
\hline RG2 & 0.384 & 0.800 & 0.380 \\
\hline RG3 & 0.435 & 0.874 & 0.429 \\
\hline RG4 & 0.409 & 0.680 & 0.221 \\
\hline RG5 & 0.478 & 0.838 & 0.583 \\
\hline RG6 & 0.295 & 0.836 & 0.416 \\
\hline RG7 & 0.370 & 0.842 & 0.487 \\
\hline RG8 & 0.458 & 0.906 & 0.490 \\
\hline RG9 & 0.569 & 0.550 & 0.429 \\
\hline SI1 & 0.624 & 0.460 & 0.861 \\
\hline SI2 & 0.599 & 0.461 & 0.897 \\
\hline SI3 & 0.444 & 0.491 & 0.858 \\
\hline SI4 & 0.526 & 0.511 & 0.878 \\
\hline SI5 & 0.563 & 0.500 & 0.887 \\
\hline
\end{tabular}

The next criterion in discriminant validity is cross-loading, where this criterion can be met if the construct of each variable is higher than the cross burden on other constructs [25]. This result can be seen in IV thickness. In Table IV it is found that there are indicators that do not meet the requirements of the RG9 indicator, thus this indicator must be excluded from the research model.

\subsection{Evaluation of the structural model}

The structural model is tested by applying the bootstrapping technique, which is a resampling technique that draws a large number of samples, from the original data. This yield estimates of path coefficients and their two-sided significance. This model is depicted in Figure 1.

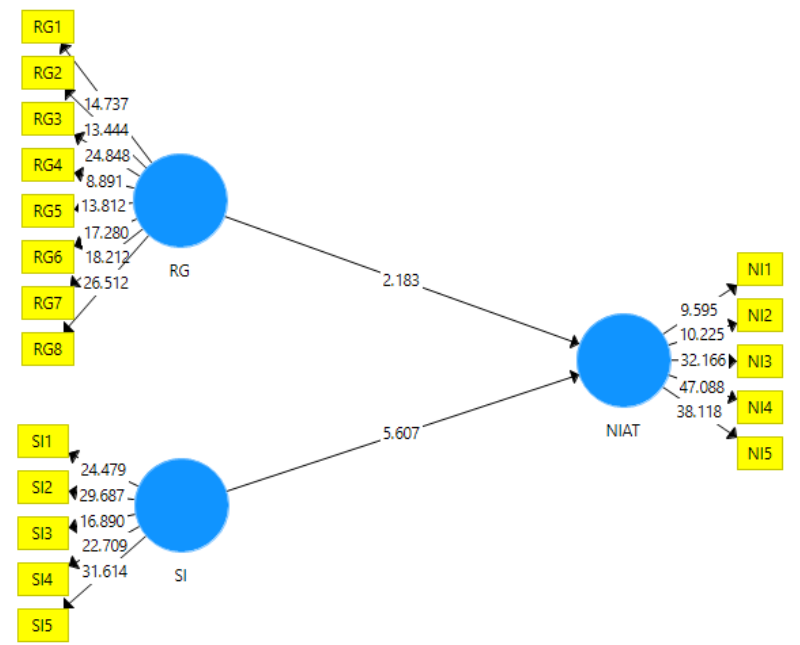

Figure 1 Path coefficients and their significance

The path coefficient and its significance can be seen in Table V. From the results of the test it can be seen that of the two hypotheses proposed all are accepted. The test results prove that there is a significant positive effect between religiosity on the intention to use sharia bank products. Likewise, with social influence, the test results show that the variable positively and significantly influences intention.

Table 5 Summary of Structural Model Results

\begin{tabular}{|lccccr|}
\hline Relationship & $\begin{array}{c}\text { Original } \\
\text { sample (O) }\end{array}$ & $\begin{array}{c}\text { Sample } \\
\text { mean }(\mathbf{M})\end{array}$ & $\begin{array}{c}\text { t-statistics } \\
(\mid \mathbf{O} / \text { STDEV } \mid)\end{array}$ & p-values & Note \\
\hline RG --> NI & 0.213 & 0.299 & 2.183 & 0.030 & Accepted \\
\hline SI --> NI & 0.529 & 0.537 & 5.607 & 0.000 & Accepted \\
\hline
\end{tabular}

From the test results as contained in table VI, it can be seen that the variables of religiosity and social influence have R2 0.441 or $44.1 \%$. These results indicate that the variables of religiosity and social influence have a strong enough correlation to the intention to use sharia Aceh bank products.

From table 6 it can also be seen that the Q2 value is 0.608 which means the Q2 value is greater than zero. These results indicate that accuracy in the category is satisfactory [26].
While seen from $\mathrm{f} 2$ the variable of religiosity has a temporary weak effect, the social influence variable has a strong effect on intention. The q2 value of the variable religiosity and social influence has a weak predictive value, because it has a value below 0.02 . 
samples that are not spread proportionally. Future research is expected to apply Theory of Planned Behavior in full in examining public responses to changes in the Aceh Syariah bank

\section{ACKNOWLEDGMENT}

Thank you to Mr. Ahmad Fuad Hasyim, as chairman of STAI Al Husain, who has provided material and non-material support. In addition, we also thank our students who are willing to collect research data, namely Elsi Mutiara Dewi and Novi Andriani.

\section{REFERENCES}

[1] Kadata.co.id, "Indonesia, Negara Berpenduduk Muslim Terbesar Dunia," 2016. [Online]. Available: https://databoks.katadata.co.id/datapublish/2016/11/11/i ndonesia-negara-berpenduduk-muslim-terbesar-dunia.

[2] P. Purwanto, "Fungsi Intermediary Bank Aceh Setelah Melakukan Konversi Menjadi Bank Umum Syariah," Ihtifaz: Journal of Islamic Economics, Finance, and Banking, vol 1, no 2, pp. 137-145, 2018.

[3] C. S. Wee, M. S. B. M. Ariff, N. Zakuan, and M. N. M. Tajudin, "Consumers Perception, Purchase Intention and Actual Purchase Behavior of Organic Food Products," Soc. Interdiscip. Bus. Res., vol. 3, no. 2, pp. 378-397, 2014.

[4] S. . Sunaryo and S. E. A. Sudiro, "The Impact of Brand Awareness on Purchase Decision: Mediating Effect of Halal Logo and Religious Beliefs on Halal Food in Malang Indonesia," Australas. J. Islam. Financ. Bus., vol. 4, no. 1, pp. 28-37, 2018.

[5] I. Ajzen, "The Theory of Planned Behavior," Organ. Behav. Hum. Decis. Process., vol. 50, no. 1, pp. 179211, 1991.

[6] A. Singh and P. Verma, "Factors influencing Indian consumers' actual buying behaviour towards organic food products," J. Clean. Prod., vol. 167, pp. 473-483, 2017.

[7] K. Maichum, S. Parichatnon, and K. Peng, "Developing An Extended Theory Of Planned Behavior Model To Investigate Consumers ' Consumption Behavior Toward Organic Food : A Case Study In Thailand,” Int. J. Sci. Technol. Res., vol. 6, no. 01, pp. 72-80, 2017.
The results of the analysis prove that the variables of religiosity and social influence have a positive and significant influence on the intention to use sharia aceh banks. The higher the level of religiosity and social influence, the higher the intention to use Aceh Syariah bank products. This study has limitations such as research 
[17] K. Zhang, C. Cheung, and M. Lee, "Examining the moderating effect of inconsistent reviews and its gender differences on consumers' online shopping decision Information Management," Int. J., vol. 34, no. 2, pp. 89-98, 2014.

[18] N. Lajuni, W. Wong, P. Ming, Y. Yacob, H. Ting, and A. Jausin, "Intention to Use Islamic Banking Products and Its Determinants," Int. J. Econ. Financ. Issues, vol. 7, no. 1, pp. 329-333, 2017.

[19] S. Wahyuni, "International Conference on Asia Pacific Business Innovation and Technology Management Moslem Community Behavior in The Conduct of Islamic Bank : The Moderation Role of Knowledge and Pricing Salamah Wahyuni," in Prosedia-Social and Behavioral Sciences, 2012, vol. 57, pp. 290-298.

[20] H. Amin, A. Rahim Abdul Rahman, S. Laison Sondoh, and A. Magdalene Chooi Hwa, "Determinants of customers' intention to use Islamic personal financing: The case of Malaysian Islamic banks," J. Islam. Account. Bus. Res., vol. 2, no. 1, pp. 22-42, 2011.

[21] M. M. H. Abou-Youssef, W. Kortam, E. AbouAish, and N. El-Bassiouny, "Effects of religiosity on consumer attitudes toward Islamic banking in Egypt," Int. J. Bank Mark., vol. 33, no. 6, pp. 1-33, 2015.

[22] I. Ghozali and H. Latan, Partial Least Square, Konsep Teknik, dan Aplikasi menggunakan program SmartPLS 3.0 untuk Penelitian Empiris. Semarang: Badan Penerbit Universitas Diponegoro., 2012.

[23] T. C. Lin and C. C. Huang, "Understanding knowledge management system usage antecedents: an integration of social cognitive theory and task technology fit," Inf. Manag., vol. 45, no. 6, pp. 410 417, 2008.

[24] C. Liao, P. Palvia, and H. N. Lin, "The roles of habit and web site quality in e-commerce," Int. J. Inf. Manage., vol. 26, no. 6, pp. 469-483, 2006.

[25] D. Chawla and H. Joshi, "Consumer attitude and intention to adopt mobile wallet in India - An empirical study," Int. J. Bank Mark., vol. 37, no. 7, pp. 15901618, 2018. 